\title{
RELATIONSHIP OF SOCIAL INTERACTION WITH LONELY IN ELDERLY AT THE SOCIAL SOCIAL SERVICE HOUSE X YOGYAKARTA
}

\author{
HUBUNGAN INTERAKSI SOSIAL DENGAN KESEPIAN PADA LANSIA DI RUMAH \\ PELAYANAN SOSIAL LANJUT USIA X YOGYAKARTA
}

Aan Devianto ${ }^{1^{*}}$, Eltanina Ulfameytalia Dewi ${ }^{2}$

ABSTRACT

Mental and social problems experienced by the elderly who live in the most frequent homes are lonely, if loneliness in the elderly is not treated, then there will be a serious impact that arises depression. Some studies suggest that the elderly who live in homes have a higher risk of loneliness than the elderly who live at home together with their families. The purpose of the research carried out is to determine the relationship of social interaction with loneliness in the elderly at the Social Services Home of the Elderly X Yogyakarta. The research method uses correlation description with cross sectional design, purposive sampling with a total sample of 51 respondents, the research instrument uses questionnaires and the analysis method uses the Kendall's Tau test. The results showed the elderly in the social services house of the elderly $X$ Yogyakarta with statistical analysis showed a significant relationship with a P-value of 0,000 $(<0,05)$ with a relationship value of $-0,508$. Conclusion There is a relationship of social interaction with loneliness in the medium category.

Keyword: Social interactions, Loneliness, Elderly

\section{INTISARI}

Kesepian adalah permasalahan mental dan sosial yang dialami oleh lansia yang tinggal di panti, apabila kesepian pada lansia tidak ditangani, maka bisa timbul dampak yang serius yaitu depresi. Beberapa penelitian menyebutkan bahwa lansia yang tinggal di panti mempunyai risiko kesepian lebih tinggi dari pada lansia yang tinggal di rumah bersama dengan keluarganya. Tujuan dari penelitian yang dilakukan adalah untuk mengetahui hubungan Interaksi sosial dengan kesepian pada lansia di Rumah Pelayanan Sosial Lanjut Usia X Yogyakarta. Metode penelitian dengan menggunakan deskripsi korelasi dengan desain cross sectional, pengambilan sampel secara purposive dengan jumlah sampel 51 responden, instrument penelitian menggunakan kuisioner dan metode analisis menggunakan uji Kendall's Tau. Hasil penelitian menunjukkan lansia di rumah pelayanan sosial lanjut usia $X$ Yogyakarta dengan analisis statistik menunjukkan adanya

Afiliasi Penulis

STIKES Guna Bangsa Yogyakarta

Korespondensi kepada

A. Devianto

aandev59@yahoo.com hubungan signifikan dengan nilai $P$-value sebesar 0,000 $(<0,05)$ dengan nilai hubungan $-0,508$. Kesimpulan terdapat Hubungan interaksi sosial dengan kesepian dalam kategori sedang.

Kata Kunci: Interaksi sosial, Kesepian, Lansia 


\section{PENDAHULUAN}

Lanjut usia atau lansia adalah suatu bagian dari proses tumbuh kembang manusia yang melalui proses dan berkembang dari bayi, anak-anak, dewasa dan akhirnya menjadi tua. Lansia merupakan proses yang alami dimana semua orang akan menjadi tua, karena masa tua merupakan masa hidup manusia yang terakhir dan akan mengalami penurunan fisik, mental dan sosial secara bertahap (Azizah, 2011).

Menurut Nugroho, (2008), proses menjadi tua bukanlah merupakan suatu penyakit, namun secara umum dapat dikatakan apabila terjadi peningkatan usia harapan hidup maka tidak bisa dipungkiri bahwa ada kemungkinan terjadinya berbagai perubahan fungsi fisiologis yang meliputi adanya perubahan fisik, mental ataupun adanya penurunan fungsi kognitif pada individu tersebut. The National Old People's Welfare Council mengemukakan bahwa penyakit atau gangguan umum pada lanjut usia ada 12 macam yakni depresi mental, gangguan pendengaran, bronkitis kronis, gangguan pada tungkai/sikap berjalan, gangguan pada sendi panggul, anemia, demensia, gangguan penglihatan, kecemasan, dekompensasi kordis, diabetes mellitus, osteomalasia dan hipoteriodisme serta gangguan defekasi.

Salah satu permasalahan sosial yang dialami oleh lansia adalah kesepian pada lansia yang tinggal di panti,hal ini dapat dilihat dari berkurangnya kegiatan dalam mengasuh anak-anak, berkurangnya teman atau relasi akibat kurangnya aktivitas di luar rumah, kurangnya aktivitas sehingga waktu luang bertambah banyak, meninggalnya pasangan hidup, ditinggalkan anak-anak karena menempuh pendidikan yang lebih tinggi diluar kota atau meninggalkan rumah untuk bekerja, anak-anak telah dewasa dan membentuk keluarga sendiri (Septiningsih \& Naimah, 2012).

Lansia yang mengalami kesepian jika tidak ditangani maka akan menimbulkan dampak yang serius yaitu depresi pada lansia yang akan semakin menarik diri dan semakin merasa tidak berguna, hal ini dapat memicu untuk keinginan bunuh diri pada lansia (Rosmanawati, 2009).

Interaksi sosial memainkan peranan yang sangat penting dalam kehidupan lansia. Kondisi kesepian dan terisolasi secara sosial akan mempengaruhi hubungan sosial, baik sesama lansia maupun dengan pengasuh. Untuk memenuhi kebutuhan hidupnya, lansia senantiasa berinteraksi dengan lingkungan sekitarnya, saling beradaptasi, saling mempelajari, menilai dan saling melengkapi. Berkurangnya interaksi sosial usia lanjut dapat menyebabkan perasaan terisolir, perasaan tidak berguna sehingga usia lanjut menyendiri atau mengalami isolasi sosial dan menyatakan bahwa seseorang yang menginjak lanjut usia akan semakin meningkat perasaan isolasinya dan kondisi ini rentan terhadap depresi (Kaplan dan Sadock, 2010). Studi pendahuluan pada November 2019 ada beberapa lansia yang mengalami isolasi diri dan juga ada lansia yang mengalami kesulitan dalam berinteraksi dengan teman satu wisma.

\section{METODE}

Jenis penelitian yang digunakan adalah kuantitatif dengan metode penelitian deskriptif korelasional dengan pendekatan cross sectional, yang dilakukan di Unit Pelaksana Teknis Rumah Pelayanan Sosial Lanjut Usia (UPT RPSLU) Budhi Dharma Yogyakarta pada bulan Januari 2020, dengan banyak sampel 51 responden yang sudah memenuhi syarat kriteria inklusi dan kriteria eksklusi, syarat kriteria inklusi antara lain, (1) Bersedia menjadi responden penelitian 
dengan menandatangani informed consent, (2) lansia yang terdaftar di UPT RPSLU Budhi Dharma Yogyakarta. Sedangkan syarat kriteria eksklusi antara lain, (1) lansia yang sedang sakit (berada di ruang pra isolasi dan isolasi), (2) lansia yang meninggal. Instrumen penelitian menggunakan kuesioner The UCLA Loneliness Scale milik Daniel W. Russel
(1996), dan kuisioner interaksi social sebanyak 20 butir.

\section{HASIL DAN PEMBAHASAN}

Hasil dan pembahasan dari Penelitian hubungan interaksi sosial dengan kesepian pada lansia di rumah pelayanan sosia llanjut usia $\mathrm{X}$ Yogyakarta dapat dilihat pada tabel dan penjelasan di bawah ini.

Tabel 1 | Distribusi frekuensi karakteristik responden di UPT RPSLU Budhi Dharma Yogyakarta tahun 2020 (n = 51)

\begin{tabular}{cccc}
\hline Karakteristik & Kategori & Frekuiensi & Presentase \\
\hline \multirow{2}{*}{ Jenis Kelamin } & Perempuan & 33 & 64,7 \\
\cline { 2 - 4 } & Laki-laki & 18 & 35,3 \\
\hline \multirow{3}{*}{ Lama tinggal } & $<1$ tahun & 8 & 15,7 \\
\cline { 2 - 4 } & $1-5$ tahun & 32 & 62,7 \\
\cline { 2 - 4 } Keluarga & $>5$ tahun & 11 & 21,6 \\
\cline { 2 - 4 } & Ada & 13 & 25,5 \\
\cline { 2 - 4 } & Tidak ada & 38 & 74,5 \\
\hline & Total & $\mathbf{5 1}$ & $\mathbf{1 0 0 , 0}$ \\
\hline
\end{tabular}

Hasil distribusi data pada Tabel 1, Tentang distribusi frekuensi karakteristik responden berdasarkan jenis kelamin diketahui bahwa responden perempuan sebanyak $33(64,7 \%)$, berdasarkan lama tinggal sebanyak $32(62,7 \%)$, memiliki lama tinggal kisaran 1-5 tahun, dan berdasarkan ada tidaknya keluarga sebanyak 38 (74,5\%) tidak memiliki keluarga.

Tabel 2 | Distribusi frekuensi kesepian pada lansia di UPT RPSLU Budhi Dharma Yogyakarta tahun 2020 ( $n=51)$

\begin{tabular}{cccc}
\hline Variabel & Kategori & Frekuensi & Persentase (\%) \\
\hline \multirow{4}{*}{ Kesepian } & Tidak kesepian & 8 & 15,7 \\
\cline { 2 - 4 } & Kesepian rendah & 16 & 31,4 \\
\cline { 2 - 4 } & Kesepian sedang & 19 & 37,2 \\
\cline { 2 - 4 } & Kesepian berat & 8 & 15,7 \\
\hline & Total & $\mathbf{5 1}$ & $\mathbf{1 0 0}$ \\
\hline
\end{tabular}

Berdasarkan hasil distribusi data pada tabel 2. tentang distribusi frekuensi kesepian pada lansia di Unit Pelaksana Teknis Rumah Pelayanan Sosial Lanjut Usia Budhi Dharma
Yogyakarta tahun 2020 diketahui bahwa kesepian pada lansia masuk dalam kategori sedang yaitu sebanyak 19 responden $(37,2 \%)$. 
Tabel 3 |Hasil Analisis Interaksi Unit Pelaksana Teknis Rumah Pelayanan SosialLanjut Usia Budhi Dharma Yogyakarta

\begin{tabular}{lcc}
\multicolumn{1}{c}{ Penilaian } & f & Presentase \\
\hline Interaksi Sosial & & \\
\hline -Kurang & 5 & $8.9 \%$ \\
\hline -Sedang & 39 & $78.6 \%$ \\
\hline -Baik & 7 & $12.5 \%$ \\
\hline \multicolumn{1}{c}{ Total } & $\mathbf{5 1}$ & $\mathbf{1 0 0 \%}$
\end{tabular}

Dilihat dari tabel diatas menunjukkan bahwa mayoritas responden memberikan penilaian variabel interaksi sosial dalam kategori sedang yaitu sebanyak 44(78,6\%). Sedangkan penilaian yang lain yaitu kurang sebanyak $5(8,9 \%)$, dan penilaian baik sebanyak 7(12,5\%). Hal ini menunjukan bahwa interaksi sosial pada lansia di Unit Pelaksana Teknis Rumah Pelayanan Sosial Lanjut Usia Budhi Dharma Yogyakarta dalam kategori sedang.

Tabel 4 Hubungan interaksisosial dengan kesepian pada lansiadi UPT RPSLU Budhi Dharma Yogyakarta tahun 2020

\begin{tabular}{|c|c|c|c|c|c|c|c|c|c|c|c|c|}
\hline Variabel & \multicolumn{8}{|c|}{ Kesepian } & & & \multirow{3}{*}{$\begin{array}{c}p- \\
\text { value }\end{array}$} & \multirow{2}{*}{$\begin{array}{c}\text { Correl } \\
\text { ation } \\
\text { coeffi- } \\
\text { cient }\end{array}$} \\
\hline \multirow{2}{*}{$\begin{array}{l}\text { Interaksi } \\
\text { Sosial }\end{array}$} & \multicolumn{2}{|c|}{$\begin{array}{c}\text { Tidak } \\
\text { kesepian }\end{array}$} & \multicolumn{2}{|c|}{$\begin{array}{l}\text { Kesepian } \\
\text { rendah }\end{array}$} & \multicolumn{2}{|c|}{$\begin{array}{l}\text { Kesepian } \\
\text { sedang }\end{array}$} & \multicolumn{2}{|c|}{$\begin{array}{c}\text { Kesepia } \\
\mathrm{n} \text { berat }\end{array}$} & \multicolumn{2}{|c|}{ Total } & & \\
\hline & $\mathrm{n}$ & $\%$ & $\mathrm{n}$ & $\%$ & $\mathrm{n}$ & $\%$ & $\mathrm{n}$ & $\%$ & $\mathbf{n}$ & $\%$ & & \\
\hline Tinggi & 0 & 0 & 1 & 2,0 & 0 & 0 & 0 & 0 & 1 & 2,0 & & \\
\hline Sedang & 7 & 13,7 & 14 & 27,4 & 10 & 19,6 & 1 & 2,0 & 32 & 62,7 & 0,000 & $-0,508$ \\
\hline Rendah & 1 & 2,0 & 1 & 2,0 & 9 & 17,6 & 7 & 13,7 & 18 & 35,3 & & \\
\hline Total & 8 & 15,7 & 16 & 31,4 & 19 & 37,2 & 8 & 15,7 & 51 & 100 & & \\
\hline
\end{tabular}

Hasil penelitianmenunjukkan bahwa terdapat hubungan yang signifikan antara interaksi sosial dan kesepian pada lansia di UPT RPSLU Budhi Dharma Yogyakarta, terdapat adanya hubungan dari kedua variabel ditunjukkan dari hasil perhitungan uji Kendall'sTau dengan nilai signifikan $p$-value $0,000(<0,05)$ dengan kekuatan hubungan antar variabel $-0,508$. Lansia di UPT RPSLU Budhi Dharma yang memiliki interaksisosial sedang sekaligus kesepian rendah sebanyak 14 responden $(27,4 \%)$. Sedangkan kesepian berat sebanyak 7 responden $(13,7 \%)$ memiliki interaksi sosial dalam kategori rendah. Hasil penelitian ini sejalan dengan penelitian Marini dan Hayati (2009), yaitu interaksi sosial yang diterima oleh subjek penelitian tergolong sedang, dan kesepian yang dialami oleh subjek penelitian tergolong sedang. Hal ini menyatakan bahwa terdapat pengaruh negatif antara Interaksi sosial terhadap kesepian, sehingga semakin tinggi interaksi sosial yang diperoleh lansia maka kesepiannya akan semakin rendah. Sebaliknya, semakin rendah interaksi sosial yang diperoleh maka semakin tinggi kesepiannya (Marini dan Hayati, 2009). Kesepian adalah perasaan negatif yang dihubungkan pada kurangnya hubungan sosial dengan orang lain dan 
merupakanakibat dari hidup sendiri, kurangnya hubungan dengan keluarga, kurangnya hubungan dengan budaya atau asalnya atau ketidakmampuan untuk berpartisipasi aktif dalam aktivitas komunitas lokal (Amalia, 2013).Penelitian ini sejalan dengan penelitian Sugiyanti (2010) di Padukuhan Kramen Sidoagung, Godean, Sleman Yogyakarta, bahwa lansia yang memperoleh interaksi sosial rendah berpeluang mengalami kesepian, sementara individu yang memperoleh dukungan sosial yang tinggi tidak merasa kesepian. Interaksi sosial dianggap dapat memperkuat fungsi kekebalan tubuh dalam merespon penyakit dan mengurangi respon fisiologis terhadap stres. Interaksi sosial berperan aktif dalam membantu pemulihan terhadap respon masalah apabila hubungan tersebut bersifat suportif yang dapat menghindarkan seseorang dari kesendirian (Taylor, 2009).

\section{KESIMPULAN}

Interaksi sosial pada lansia di Unit Pelaksana Teknis Rumah Pelayanan Sosial Lanjut Usia Budhi Dharma Yogyakarta sebagian besar dalam kategori sedang, kesepian pada lansia di Unit Pelaksana Teknis Rumah Pelayanan Sosial Lanjut Usia Budhi Dharma Yogyakarta sebagian besar dalam kategori sedangdan terdapat hubungan antara interaksi sosial dengan kesepian pada lansia di Unit Pelaksana Teknis Rumah Pelayanan Sosial Lanjut Usia Budhi Dharma Yogyakarta dengan $p$-value $0,000<0,05$ dengan nilai hubungan $-0,508$.

\section{DAFTAR PUSTAKA}

Azizah, M.L., 2011, Keperawatan Lanjut Usia, Yogyakarta: Grahallmu.

Nugroho, W.H., 2008, Keperawatan Gerontik \& Geriatrik, Jakarta: EGC.
Rosmanawati, M., 2009, Hubungan Kesepian dengan Depresi pada Lanjut Usia (Lansia) di RW Kebroan Kelurahan Pandeyan Kecamatan Umbulharjo Yogyakarta.Journal.

Kaplan \&Sadock. 2010, Buku Ajar Psikiatri Klinis. Ed. 2, Jakarta: EGC.

Nawawi. U., 2009, Sehat \& bahagia di usia senja. Yogyakarta: DianlokaPrintika.

Taylor, S.E., Peplau, L.A., \& Sears, D.O., 2009, Psikologi Sosial. Edisi Kedua belas. Alih Bahasa: Tri Wibowo, B.S., Jakarta: KencanaPrenada Media Group.

TamherS. \&Noorkasiani. 2009, Kesehatan Usia Lanjut dengan Pendekatan Asuhan Keperawatan, Jakarta: SalembaMedika.

Amalia, A.D., 2013, Kesepian dan Isolasi Sosial yang Dialami Lanjut Usia: Tinjauan dari Perspektif Sosiologis, Ejournal. kemsos.go.id. 